\title{
KONSEP PENDIDIKAN ISLAM BERDASARKAN \\ AL-QURAN AL-KARIM
}

\section{Muhammad Arif \\ Penulis adalah Dosen Manajemen Pendidikan Ilsam Pada Fakultas Tarbiyah dan Ilmu Keguruan IAIN Lhokseumawe}

\begin{abstract}
The concept of education in the Qur'an is the best educational concept in the world. It is because the Qur'an is a revelation of God. Education of the Qur'an is a guidance for humans beings to be happy and safe in the world and the hereafter. The concept of education has succeeded in giving birth to the best human generation. They are the generation that the Prophet guided by guidance of the Qur'an. So that the succees is re-realized then the concept of education in the Qur'an should be applied.
\end{abstract}

Keywords: Islamic education, the Qur'an

\section{PENDAHULUAN}

Al-Quran merupakan petunjuk hidup manusia yang tidak ada keraguan padanya. Di dalamnya terdapat prinsip-prinsip dasar yang menyangkut kehidupan umat manusia, mulai dari tujuan penciptaan, fungsi dan peranan manusia serta amalanamalan yang mesti dikerjakan selama hidup di dunia. Salah satu pembahasan yang banyak mendapat perhatian di dalam al-Quran adalah masalah pendidikan. Pendidikan adalah suatu yang fundamental dalam ajaran Islam. Banyak ayat-ayat al-Quran yang memotivasi manusia untuk melaksanakan proses pendidikan, seperti menuntut ilmu, mengajar, serta membina generasi muda dengan ilmu pengetahuan dan teknologi.

Pentingnya pendidikan sudah diisyaratkan al-Quran semenjak wahyu pertama diturunkan. Wahyu pertama yang diterima nabi Muhammad saw di Gua Hira bukanlah perintah untuk mengerjakan sholat ataupun puasa, akan tetapi berisikan perintah untuk membaca. Firman Allah swt:

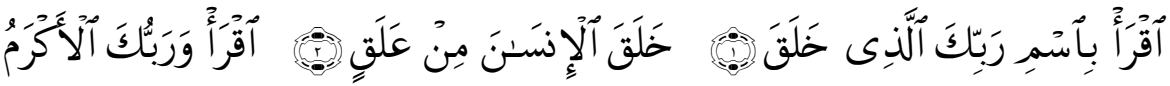

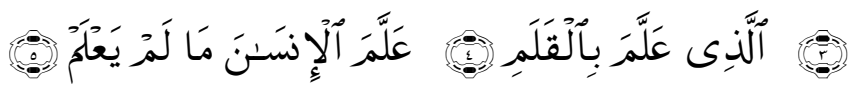


manusia dengan Pena. Ia mengajarkan manusia apa yang tidak diketahuinya.” (QS. al-“Alaq: 1 - 5)

Lewat wahyu pertamanya al-Quran menegaskan kepada umat manusia kalau pendidikan merupakan unsur terpenting dalam kehidupan. Bagi umat Islam sendiri pendidikan tidak hanya sekedar mengasah kemampuan intelektual semata, tapi lebih daripada itu untuk menanamkan nilai-nilai Islam dalam kehidupan nyata sehingga akan lahir intelektual-intelektual muslim yang senantiasa taat dan patuh menjalankan agamanya.

\section{PEMBAHASAN}

Sebagai suatu yang urgen dalam kehidupan, pendidikan haruslah dikelola dengan sebaik-baiknya agar hasil yang diperoleh sesuai dengan harapan. Untuk itu di dalam bahasan ini akan dipaparkan beberapa aturan tentang tata cara pelaksanaan pendidikan sesuai petunjuk al-Quran al-Karim.

\section{A. Tujuan Pendidikan Dalam Al-Quran}

Tujuan pendidikan bagi manusia tak terlepas dari tujuan hidup maunusia itu sendiri. Tujuan hidup manusia secara tegas telah dijelaskan oleh Allah swt di dalam 2 ayat dalam Al-Quran yaitu:

1. Surat az-Zariyaat ayat 56 :

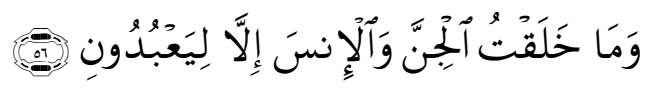

"Dan tidaklah Aku ciptakan jin dan manusia melainkan agar mereka beribadah kepadaKu”.

Di dalam ayat diatas, Allah swt menyatakan bahwa tujuan penciptaan manusia adalah untuk beribadah kepadaNya. Untuk menggapai tujuan tersebut maka segala aktifitas yang dilakukan manusia haruslah dalam rangka ibadah. Dan itu akan terwujud jika amalan yang dilakukan adalah semata-mata karena Allah swt. Begitu juga dengan pendidikan, pendidikan hanyalah akan bernilai ibadah kalau diniatkan untuk mendapatkan ridha Allah swt. Inilah benang merah yang membedakan pendidikan seorang muslim dengan non muslim. Seorang Muslim beribadah ketika menuntut ilmu dan mendapatkan pahala di sisi Allah swt, sementara non muslim tidak mendapatkan keistimewaan tersebut.

Dengan menjadikan ridha Allah sebagai tujuan maka seorang muslim dalam melakukan proses pendidikan dituntut untuk selalu menjaga norma-norma dan aturan- 
aturan yang sesuai dengan ketentuan ilahi. Berlaku jujur, tidak menipu, menjauhi praktek KKN serta tidak melalaikan kewajiban kepada Allah merupakan karakter pendidikan dalam al-Quran. Sebab pendidikan dalam al-Quran tidak hanya menekankan pada pengajaran yang berorientasi pada kecerdasan intelektualitas, tapi lebih menekankan pada pembentukan karakter dan kepribadian yang utuh. Pendidikan dalam al-Quran berorientasi untuk pembinaan manusia seutuhnya, sebagaimana ditegaskan dalam firman Allah ta'ala:

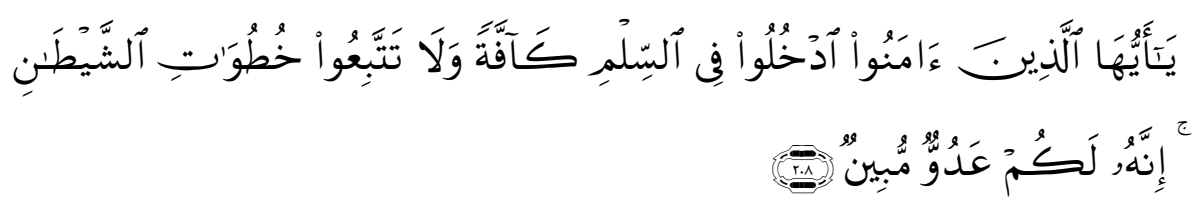

"Wahai orang-orang Yang beriman! masuklah kamu ke dalam agama Islam secara keseluruhan, dan janganlah kamu mengikuti langkah-langkah Syaitan; Sesungguhnya Syaitan itu adalah musuh yang nyata bagimu”. (QS. al-Baqarah: 208)

2. Surat al-Baqarah ayat 30 :

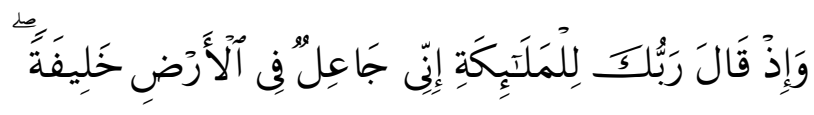

"Dan (ingatlah) ketika Tuhanmu berfirman kepada Malaikat;

"Sesungguhnya Aku hendak menjadikan seorang khalifah di bumi".

Di dalam ayat ini dijelaskan bahwa tujuan manusia disamping beribadah adalah untuk menjadi khalifah (pemimpin) di muka bumi. Maksud menjadi khalifah ialah bahwa manusia adalah makhluk yang diamanahi untuk memimpin dan mengelola bumi beserta segala isinya. Pengelolaan manusia terhadap bumi adalah dalam rangka melestarikan, memakmurkan serta menjaganya dari berbagai kerusakan. Untuk itu maka pendidikan yang dilakukan manusia harus bisa melahirkan individu-individu yang bisa melestarikan, menjaga, dan memanfaatkan hasil bumi ini untuk kemashlahatan bersama.

Inilah 2 tujuan mulia pendidikan dalam al-Quran. Pertama beribadah kepada Allah, maka pendidikan yang dilaksanakan harus bisa melahirkan pribadi-pribadi yang taat kepada Allah swt. Imam Al-Ghazali mengatakan "Sesungguhnya hasil ilmu itu adalah mendekatkan diri kepada Allah, Tuhan semesta alam". ${ }^{1}$ Tujuan kedua menjadi pemimpin di muka bumi dalam rangka melestarikan dan menjaga kemakmurannya,

\footnotetext{
${ }^{1}$ Abuddin Nata, 1997, Filsafat Pendidikan Islam, Jakarta: Logos Wacana Ilmu, hal 162.
} 
maka pendidikan yang dilaksanakanpun harus bisa mencetak generasi-generasi yang selalu menjaga kelestarian dan kemakmuran bumi bukan malah melahirkan sarjanasarjana yang membuat berbagai macam kerusakan.

Jadi pendidikan dalam al-Quran bukanlah pendidikan yang mengajarkan hubungan dengan Allah semata dan melupakan dunia, atau pendidikan yang mementingkan dunia dan melupakan sang Pencipta, akan tetapi pendidikan dalam alQuran adalah pendidikan yang menghubungkan manusia dengan Tuhannya untuk kemaslahatan hidupnya di dunia. ${ }^{2}$ Pendidikan dalam al-Quran menghendaki semakin bertambah ilmu seseorang maka bertambah pula ketaatannya kepada Sang Pencipta serta semakin bermanfaat bagi lingkungan dan alam sekitarnya.

\section{B. Objek Pendidikan dalam Al-Quran}

Objek pendidikan dalam al-Quran dapat dibagi menjadi 3 kategori. Pertama individu, kedua keluarga dan orang-orang terdekat, ketiga masyarakat.

1. Individu

Maksud dari individu disini adalah bahwa yang menjadi objek pendidikan tersebut adalah diri sendiri. Mendidik dan membina diri merupakan aspek yang penting dalam pendidikan. Makanya di dalam al-Quran dikatakan:

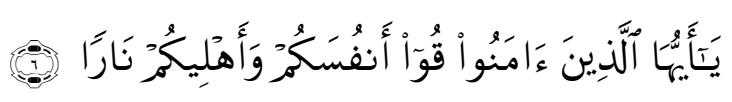

"Wahai orang-orang yang beriman! peliharalah diri kamu dan

keluarga kamu dari api neraka”. (QS. at-Tahrim: 6)

Dalam ayat ini Allah memerintahkan kepada orang beriman untuk menjaga dirinya terlebih dahulu sebelum keluarganya. Sebab seorang pendidik menurut alQuran tidak hanya mendidik dengan tutur kata dan ucapannya. Akan tetapi seorang pendidik harus bisa menjadi contoh dan tauladan bagi anak didiknya. Inilah pendidikan yang dipraktekkan oleh Rasulullah saw sebagaimana ditegaskan oleh Allah swt dalam firmanNya:

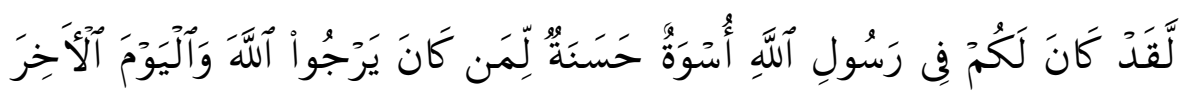

$$
\begin{aligned}
& \text { وَذَكَرَ ألَّهَ كَثِيرًا }
\end{aligned}
$$

"Demi sesungguhnya adalah bagi kamu pada diri Rasulullah itu contoh tauladan yang baik, yaitu bagi siapa yang mengharapkan

\footnotetext{
${ }^{2}$ Muhammad Qutb, 2001, Manhaj Tarbiyah Islamiyah, Kairo: Dar Syuruq, hal 17.
} 
rahmat Allah dan hari akhir serta mengingat Allah banyakbanyaknya." (QS. al-Ahzab: 21)

Oleh karena itu maka sebelum mangajak dan mendakwahi orang lain maka individu harus diperbaiki terlebih dahulu. Amatlah janggalnya ketika kita mengajak dan menyuruh orang lain untuk berbuat kebaikan sementara diri kita sendiri tidak mengerjakannya. Inilah yang dikecam oleh Allah di dalam surat as-Shaf ayat 3:

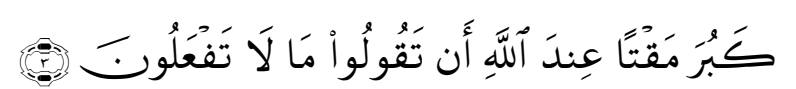

"Amat besar kemurkaan di sisi Allah jika kamu mengatakan sesuatu yang tidak kamu lakukan"”.

Dalam membina individu al-Quran sangat menekankan agar setiap diri selalu menjaga hubungannya dengan Allah swt. Menjaga hubungan dengan Allah akan melahirkan muraqabatullah (merasa diawasi oleh Allah). Ketika seseorang merasa selalu diawasi oleh Allah maka ia tidak akan melakukan perbuatan-perbuatan yang dilarang kapan dan dimanapun ia berada.

2. Keluarga dan orang-orang tedekat

Keluarga adalah objek kedua pendidikan setelah individu, sebagaimana ditegaskan di dalam firman Allah surat At Tahrim ayat 6 diatas; (Jagalah dirimu) selanjutnya Allah mengatakan: (dan keluargamu). Dakwah kepada keluarga dekat adalah dakwah yang dilakukan oleh para nabi termasuk nabi Muhammad saw. Sebagaimana firman Allah Swt dalam surat As-Syu'ara' ayat 214:

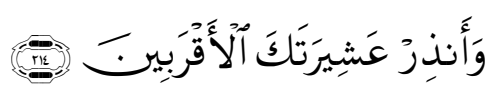

"Dan berilah peringatan kepada kaum kerabatmu yang terdekat".

Oleh karena itulah orang yang pertama kali masuk Islam adalah dari golongan keluarga dan kerabat dekat Rasulullah saw. Dari golongan wanita Khadijah isteri Rasulullah saw, dari golongan anak-anak Ali bin Abi Thalib sepupu Rasulullah saw, dari kalangan orang dewasa Abu Bakar, kolega sekaligus sahabat karib Rasulullah saw. Barangkali hikmah dari berimannya kerabat sebelum orang lain adalah karena kerabat merupakan orang terdekat yang apabila mereka beriman tentu akan menjadi 
dalil bagi yang lain, tapi ketika kerabat dekat tidak beriman tentu orang lain juga akan sulit untuk menerima dakwahnya. ${ }^{3}$

Al-Quran juga banyak mengisahkan tentang peranan orang tua dalam mendidik dan membina keluarga. Nabi Ibarahim as mendidik putranya Ismail as, sehingga Ismail tumbuh menjadi pribadi yang patuh dan taat menjalankan perintah ilahi, nabi Ya'kub mendidik nabi Yusuf sehingga Yusuf tumbuh menjadi pribadi yang pemurah, penyabar dan pamaaf. Luqmanul Hakim mendidik anaknya menjadi pribadi yang taat dan bertakwa kepada Allah swt.

3. Masyarakat

Rasulullah diutus oleh Allah swt tidak hanya untuk menshalihkan individu tertentu, atau keluarga tertentu, akan tetapi untuk menshalihkan semua orang yang menginginkan kebaikan dunia dan akhirat. Firman Allah:

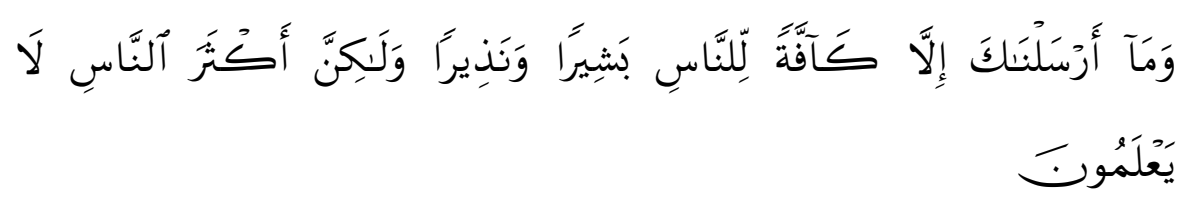

"Dan tiadalah Kami mengutusmu (Wahai Muhammad) melainkan untuk umat manusia seluruhnya, sebagai pemberi kabar gembira dan ancaman, akan tetapi kebanyakan manusia tidak mengetahui”.

Kepedulian Islam terhadap pembinaan masyarakat sudah tidak diragukan lagi. Bahkan umat terbaik yang merupakan ciri utama umat Islam tidaklah disematkan melainkan terhadap mereka yang peduli terhadap kondisi masyarakatnya. Firman Allah swt:

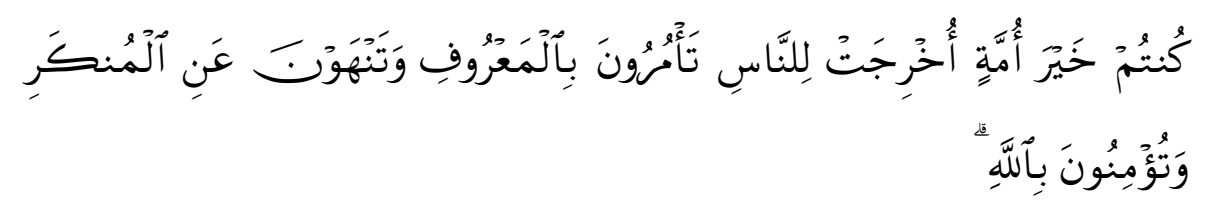

"Kalian adalah umat terbaik yang dikeluarkan untuk manusia, mengajak kepada yang ma'ruf dan mencegah dari yang munkar serta beriman kepada Allah”. (QS. Ali Imran: 110)

Sebaliknya Allah mencela mereka yang egois, yang hanya mementingkan individunya dan tidak peduli dengan keadaan orang lain. Firman Allah:

\footnotetext{
${ }^{3}$ Sulaiman bin Muhammad, al-Anwar fi sirati an-Nabiyi al-Mukhtar, hal 13
} 


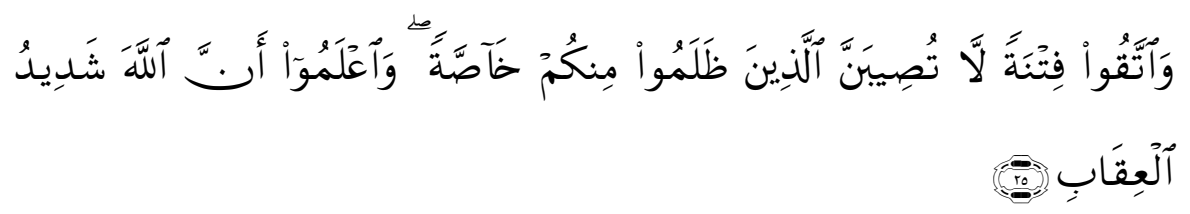

"Dan takutlah kalian kepada bencana yang tidak saja menimpa orang-orang yang zalim di antara kalian secara khusus (tetapi akan menimpa kalian secara umum). dan ketahuilah bahwa Allah Maha keras siksaNya”. (QS. Al-Anfal: 25)

Ayat ini mengindikasikan bahwa setiap individu janganlah merasa aman ketika pribadinya sudah sholeh, padahal di sekelilingnya masih banyak orang berbuat zhalim. Imam As-Suyuthi di dalam menafsirkan ayat diatas menukil perkataan Ibnu Abbas menyatakan bahwa dalam ayat ini Allah memerintahkan umat Islam untuk tidak membiarkan kemunkaran. Jika tidak, maka Allah akan meratakan azab kepada mereka baik yang zhalim ataupun yang tidak. ${ }^{4}$ Oleh karenanya pendidikan terhadap masyarakat harus terus digalakkan.

\section{Materi Pendidikan dalam al-Quran}

Materi pendidikan yang akan diajarkan semuanya tidak sama. Ada yang menjadi prioritas dan harus diajarkan sedini mungkin dan ada yang harus menunggu waktu-waktu tertentu untuk diajarkan. Orang tua dan pendidik harus memahami hal ini, sehingga pendidikan yang dilakukan lebih efektif dan tepat sasaran. Banyak terjadi karena kurang memahami masalah prioritas, seorang pendidik mengajarkan hal-hal yang tidak penting dan meninggalkan hal-hal yang penting, atau mengajarkan hal-hal yang penting dan mengabaikan hal-hal yang lebih penting. Hal ini akan berdampak buruk terhadap keberhasilan pendidikan itu sendiri. Untuk itu materi apa yang seharusnya menjadi prioritas dalam pendidikan?

Jawaban pertanyaan tersebut tentunya dengan melihat kepada ayat-ayat alQuran sendiri, sebab al-Quran disamping sebagai kitab petunjuk merupakan kitab pendidikan nomor satu bagi umat manusia yang telah terbukti dan berhasil melahirkan generasi terbaik sepanjang masa. Dengan mempelajari ayat-ayat al-Quran setidaknya terdapat tiga materi utama pendidikan yang terdapat dalam al-Quran:

1. Materi Tauhid

Tauhid merupakan inti risalah para nabi mulai dari nabi Adam sampai nabi Muhammad saw. Sebagaimana dalam firman Allah swt:

\footnotetext{
${ }^{4}$ As-Suyuthi, 2003, Ad-Dur Mantsur fi Tafsir bil Ma'tsur, Kairo: Dar Hijr, j 7, hal 89.
} 


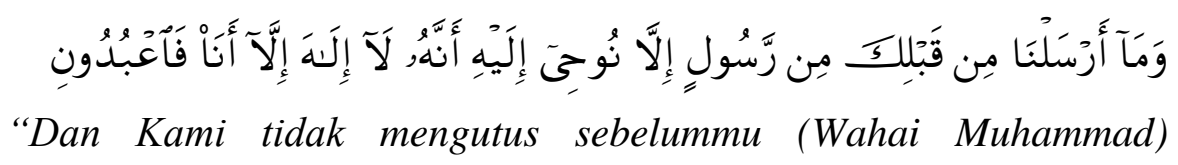
seseorang Rasul pun melainkan Kami wahyukan kepadanya: "Bahwa Sesungguhnya tiada Tuhan (yang berhak disembah) melainkan Aku; oleh karena itu, maka Beribadahlah kepadaku". (QS. Al-Anbiya': 25).

Perkara tauhid merupakan perkara paling mendasar yang harus diketahui oleh setiap manusia. Keyakinan akan keesaan Allah serta menjadikanNya sebagai satusatunya Zat yang pantas untuk disembah akan melahirkan kataatan dan kedisiplinan dalam menjalankan perintah ilahi. Sebab dengan tauhid seorang mukmin yakin bahwa Allah maha mengetahui dan tidak ada satupun yang bisa disembunyikan dari Allah. Untuk itu ia akan selalu melakukan kebaikan. Hal ini sebagaimana dicontohkan oleh Lukmanul Hakim ketika menjadikan tauhid sebagai nasehat pertama yang disampaikannya kepada putranya, firman Allah swt:

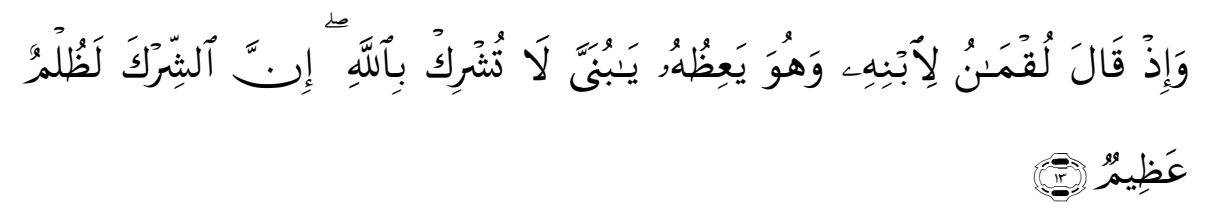

"Dan (ingatlah) ketika Luqman berkata kepada anaknya, semasa ia memberi nasihat kepadanya:" Wahai anakku, janganlah Engkau mempersekutukan Allah, sesungguhnya perbuatan syirik itu adalah suatu kezaliman yang besar". (QS. Luqman: 13)

Penanaman nilai-nilai tauhid haruslah menjadi landasan pendidikan Islam. Tidak ada pendidikan tanpa kayakinan, tidak ada pula akhlak dan etika tanpa keimanan. Apabila iman lurus maka lurus pulalah aspek kehidupannya. Sebab iman mengajarkan manusia untuk selalu mawas diri dan takut kepada Allah swt. Inilah yang diajarkan oleh Rasulullah saw dalam mendidik para Sahabatnya. Selama lebih kurang 13 tahun di Mekkah membina akidah dan menanamkan nilai-nilai ketauhidan, sehingga ketika turun perintah maupun larangan Allah tidak ada pilihan mereka kecuali mengatakan sami'na wa atha'na (kami dengar dan kami ikuti).

Hal berbeda terjadi ketika pemerintah Amerika Serikat mencoba menerapkan larangan miras di negaranya. Berbagai usaha dilakukan, mulai dari pengerahan media cetak dan elektronik - guna menjelaskan bahaya miras serta meningkatkan hukuman dan denda bagi yang mengkonsumsinya. Namun setelah 14 tahun pemberlakuan 
larangan tersebut yang terjadi sungguh mencengangkan. Pemerintah Amerika Serikat mengalami kerugian yang luar biasa; Sekitar 300 orang mati dibunuh dan dipenjara lebih dari 500.000 orang, belum lagi dana yang terkuras untuk biaya iklan dan himbauan untuk tidak mengkonsumsi miras yang mencapai angka ratusan juta dolar. Semua itu ternyata tidak mengurangi jumlah pecandu miras di negaranya. Sehingga pada tahun 1933 pemerintah Amerika Serikat terpaksa mencabut kembali larangan tersebut dan membiarkan peredaran miras secara legal di negaranya. ${ }^{5}$

Kecanduan masyarakat Arab dahulunya dalam mengkonsumsi miras juga tidak kalah dengan kecanduan penduduk Amerika. Tiada jamuan dan pertemuan yang tidak dibarengi dengan miras. Akan tetapi ketika datang larangan Ilahi tentang pengharaman miras, semuanya taat dan patuh sehingga jalan-jalan kota Madinah menjadi tergenang akibat banyaknya kendi-kendi miras yang ditumpahkan. ${ }^{6}$ Begitulah dahsyatnya ketika pendidikan didasari dengan akidah yang kokoh dan iman yang kuat kepada Allah swt. Sebaliknya pendidikan yang kosong dari nilai-nilai keimanan hanyalah akan menghasilkan ketaatan yang semu, taat pada satu kondisi, tapi melanggar pada kondisi yang lain.

2. Materi Ibadah

Ibadah merupakan materi kedua yang harus ditanamkan kepada peserta didik. Sebab ibadah merupakan buah dari keimanan seseorang. Ketika seseorang mengaku beriman kepada Allah maka konsekwensi dari keimanannya itu adalah beribadah kepadaNya, sebagaimana yang ditegaskan dalam FirmanNya:

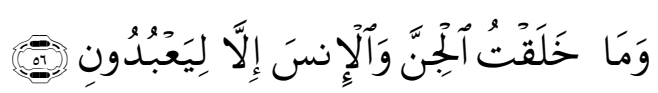

"Dan tidaklah Aku ciptakan jin dan manusia melainkan agar mereka beribadah kepadaKu”. (Az-Dzariyat: 56)

Pentingnya pendidikan ibadah ini juga ditunjukkan Allah swt di dalam alQuran ketika Allah memerintahkan nabi Muhammad saw agar mengajarkan shalat kepada keluarganya. Firman Allah swt:

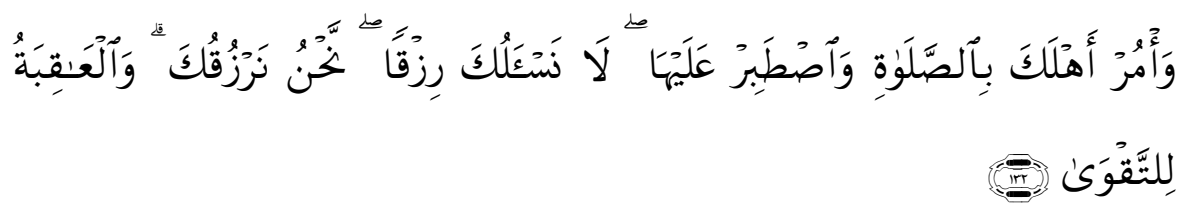

\footnotetext{
${ }^{5}$ Abu Hasan Ali al-Hasani an-Nadawi, Maza Khasiral 'Alam bi Inhithatil Muslimin, hal 51, dari kitab Tanqihat karangan al-Maududi.

${ }^{6}$ Muhammad Syadid, t.t, Manhaj al-Quran fi at-Tarbiyah, Kairo: Dar Tauzi' wa Nasyr, hal 13.
} 
"Dan perintahkanlah keluargamu mengerjakan shalat, dan bersabarlah atasnya, Kami tidak meminta rezeki kepadamu, (bahkan) Kamilah yang memberi rezeki kepadamu. dan (ingatlah) kesudahan yang baik adalah bagi orang-orang yang bertaqwa. (QS. Thaha: 132).

Perintah kepada nabi Muhammad berarti juga perintah kepada umatnya selama tidak ada dalil yang menunjukkan pengkhususan. Dan tidak ada dalil yang menunjukkan pengkhususan dalam ayat diatas, sehingga wajib hukumnya bagi setiap orang tua untuk memperhatikan anak-anak mereka dalam perkara shalat. Saking pentingnya pendidikan shalat, Rasulullah saw bahkan memerintahkan orang tua untuk mengajarkan shalat kepada anaknya ketika mereka masih kecil. Dalam sebuah riwayat dari Amru bin Syu'aib bahwa Rasul saw bersabda:

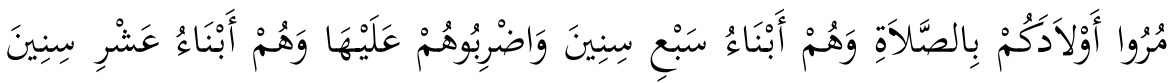

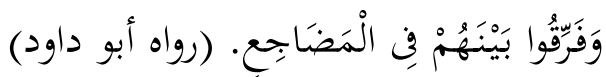

"Perintahkanlah anakmu shalat pada umur tujuh tahun dan pukullah mereka jika mereka enggan ketika berumur 10 tahun, dan pisahkanlah tempat tidur mereka (anak laki-laki dan perempuan). (HR. Abu Daud).",

Hadis di atas mengharuskan kepada orang tua untuk melakukan pengawasan sejak usia dini terhadap anak-anak mereka. Semenjak berumur tujuh tahun anak-anak sudah diperintah dan dianjurkan untuk mendirikan shalat. Dan tatkala mereka berumur sepuluh tahun apabila mereka melalaikan shalat maka hendaklah dipukul dengan pukulan yang mendidik bukan pukulan yang menyakiti.

Begitulah seharusnya pendidikan yang diajarkan kepada peserta didik. Sehingga anak tumbuh menjadi pribadi yang taat dan patuh kepada perintah Allah swt. Situasi ini bertolak belakang dengan realita yang terjadi di masyarakat saat sekarang ini. Dimana kebanyakan orang tua lalai terhadap kewajiban yang satu ini. Seorang bapak tidak bisa menjadi contoh dan panutan dalam menjaga shalat, akibatnya anakanaknya tumbuh menjadi generasi yang tidak peduli dan melalaikan shalatnya. Padahal mengabaikan pendidikan shalat terhadap anak merupakan bentuk kejahatan yang tiada bandingannya.

\footnotetext{
${ }^{7}$ Riwayat Imam Ahmad, no 6756, Abu Daud, no 495, Hakim 1/311 dan dishahihkan oleh Imam Albani dalam Shahihul Jami', no 5868.
} 
Imam Ibnu Qayyim mengatakan: "Barangsiapa melalaikan pendidikan anak, tidak mengajarkan mereka hal-hal yang bermanfaat baginya serta dia membiarkan anaknya begitu saja, maka sungguh ia telah berlaku sangat jahat pada anaknya. Dan kebanyakan anak-anak rusak akibat kelalaian orang tua mereka dalam mengajarkan kepada anak-anak mereka hal-hal yang wajib di dalam agama ini dan hal-hal yang sunnah. Karena orang tua telah menyia-nyiakan anak-anak mereka tatkala mereka masih kecil, maka mereka tidak akan bisa mengambil manfaat dari anak-anak mereka dan anak-anak mereka tidak akan pernah bisa memberi manfaat kepada orang tua mereka tatkala mereka dewasa". ${ }^{8}$

Begitulah pentingnya pendidikan ibadah ditanamkan semenjak dini. Ketika hal tersebut diabaikan maka yang akan muncul hanyalah individu-individu perusak, yang berbuat hanya untuk kepentingan pribadi tanpa memikirkan kemashlahatan bersama.

3. Materi Akhlak

Akhlak merupakan pilar yang sangat penting dalam Islam. Akhlak yang mulia merupakan pertanda kematangan iman serta merupakan kunci kesuksesan hidup di dunia dan di akhirat. Nabi Muhammad saw sebagai rasul dan nabi terakhir diutus oleh Allah swt untuk menyempurnakan akhlak manusia. Dalam hadisnya Rasulullah saw bersabda:

"Sesungguhnya aku diutus untuk menyempurnakan Akhlak manusia”. (H.R Bukhari, bab adab al-Mufrad, lihat As-Shahihah, no 45).

Bahkan pelaksanaan syariat Islam yang banyak dan beraneka ragam itu pada hakikatnya bermuara pada pembentukan akhlak yang mulia. Makanya ketika berbicara tentang manfaat shalat Allah swt berfirman:

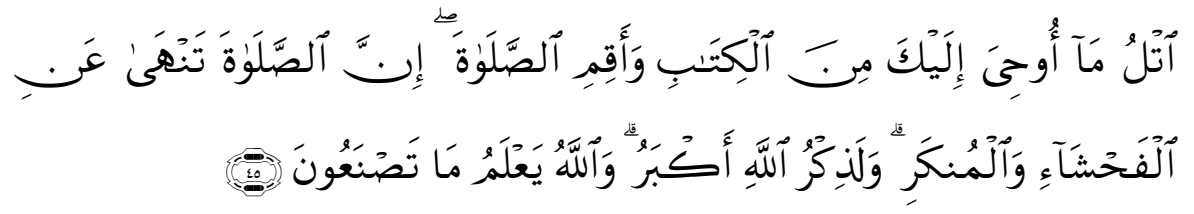

"Bacalah (hai Muhammad) apa yang diwahyukan kepadamu dari alQuran, dan dirikanlah shalat, Sesungguhnya shalat itu mencegah dari perbuatan keji dan mungkar; dan Sesungguhnya mengingat Allah adalah lebih besar (faedahnya); dan Allah mengetahui apa yang kamu kerjakan”. (QS. al-Ankabut: 45).

\footnotetext{
${ }^{8}$ Ibnu Qayyim al-Jauziyah, 1971, Tuhfatul Maudud bi ahkamil maulud, Damaskus: Dar Bayan, hal 229.
} 
Ayat di atas secara tegas menyatakan bahwa muara dari ibadah shalat adalah terbentuknya pribadi yang terbebas dari perbuatan keji dan munkar. Yang intinya adalah terbentuknya manusia yang berakhlak mulia. Rasulullah saw dalam banyak hadisnya sangat menekankan akan urgensi akhlak dalam kehidupan. Bahkan akhlak bisa menentukan kualitas keimanan seseorang. Dalam sebuah hadisnya Rasulullah saw menyatakan:

"Demi Allah ia tidak beriman, Demi Allah ia tidak beriman, Demi Allah ia tidak beriman. Para Sahabat Bertanya: Siapa mereka ya Rasulullah? Rasul menjawab: Orang yang tetangganya tidak merasa aman dari gangguannya". 9

Hadis ini secara jelas mengandung arti bahwa orang yang berakhlak buruk kepada tetangganya oleh Rasulullah dianggap tidak beriman. Ini menunjukkan bahwa berakhlak jelek bukanlah ciri dan tabiat orang yang beriman. Untuk itu adalah sebuah kewajiban bagi setiap muslim untuk senantiasa berakhlak mulia dalam setiap tindak tanduknya. Pendidikan akhlak harus ditanamkan sejak dini. Perlu diingat bahwa Rasulullah saw tidak hanya menyampaikan dakwah melalui lisan kepada umatnya. Namun yang menjadi rahasia besar keberhasilan Rasulullah dalam berdakwah adalah kemampuan beliau menjadi suri tauladan dan kemuliaan akhlaknya. Kemuliaan akhlak Rasulullah serta ajaran yang dibawanya untuk mewujudkan akhlak yang mulia telah berhasil melahirkan generasi-genarasi tangguh insan kamil yang berakhlak mulia. Pantaslah bila Allah memuji beliau dalam firmanNya:

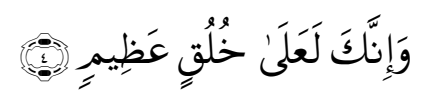

"Dan Sesungguhnya Engkau mempunyai akhlak yang amat mulia".

(QS. al-Qalam: 4)

Tiga hal di atas haruslah menjadi prioritas utama seorang pendidik untuk diajarkan kepada peserta didiknya sebelum mengajarkan ilmu-ilmu lainnya. Sebab kalau yang tiga ini luput maka sia-sialah ilmu yang didapatkan oleh peserta didik. Tidak akan ada manfaatnya jika seorang pendidik mampu mendidik anaknya menjadi ahli matematika, ahli kimia, ahli fisika dan lain sebagainya, namun ia gagal mengajarkan ketauhidan. Akibatnya anak akan berbuat syirik. Begitu juga jika ia gagal

\footnotetext{
${ }^{9}$ Bukhari, Shahih al-Bukhari, no 6016 dan Ahmad, II/288, 336.
} 
dalam menanamkan nilai-nilai kebaikan, anak akan tumbuh dengan akhlak yang buruk, tidak beretika dan jauh dari norma-norma.

\section{Dimensi Pendidikan Dalam Al-Quran}

Sebagai kitab yang komprehensif pendidikan dalam al-Quran memberikan porsi yang seimbang dalam membina manusia seutuhnya. Manusia adalah makhluk mulia yang dipilih oleh Allah swt untuk menjadi pemelihara dan pengelola bumi. Untuk menjalankan misi tersebut tubuh manusia dibekali dengan 3 komponen, yaitu ruhi, fikri dan jasadi. Pendidikan dalam al-Quran sangat menekankan pembinaan ketiga komponen tersebut dan tidak menelantarkannya. Mengabaikan salah satu komponen berarti menzholimi diri manusia itu sendiri. Orang yang hanya mementingkan aspek ruhi semata dan melupakan hak-hak fikri dan jasmaninya akan jatuh pada kesesatan. Sebaliknya larut dalam mengasah pemikiran tanpa dibarengi dengan pembinaan ruhi akan banyak salah daripada benarnya. Begitu juga tenggelam dalam ritual-ritual ruhi dan aktivitas-aktivitas fikri tapi mengabaikan hak-hak jasmani akan menyebabkan seseorang jatuh dalam kebinasaan. Untuk lebih jelasnya kita akan lihat bagaimana pembinaan ketiga komponen ini dalam al Qur'an:

1. Pendidikan Rohani

Dalam mendidik rohani seseorang, Islam sangat menekankan kepada umat manusia agar selalu menjaga hubungannya dengan Allah swt. Kapan dan dimanapun ia berada, setiap manusia harus mayakini bahwa Allah selalu memperhatikannya. Firman Allah swt:

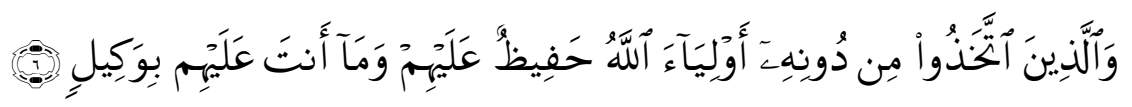

"Dan (sebaliknya) orang-orang yang menjadikan selain Allah sebagai Pelindung (yang disembah dan diharapkan pertolonganNya), Allah senantiasa mengawasi tingkah laku mereka (serta akan membalasnya); dan Engkau (Wahai Muhammad hanyalah penyampai) bukanlah menjadi wakil terhadap amalan mereka”. (QS as-Syuura: 6)

Dan juga Firman Allah di dalam surat al-An'am ayat 3:

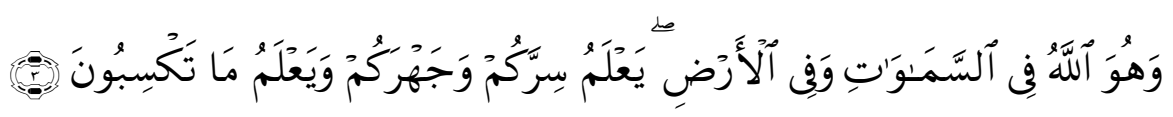

"Dan Dia lah Allah (yang disembah dan diakui kekuasaanNya) di langit dan di bumi; ia mengetahui apa yang kamu rahasiakan dan apa 
yang kamu tampakkan, dan ia juga mengetahui apa yang kamu usahakan".

Merasa diawasi oleh Allah swt akan melahirkan 2 hal; pertama ketaatan dalam menjalankan perintah Allah, kedua akan selalu takut dan malu untuk melakukan perbuatan-perbuatan yang tidak diridhoiNya.

2. Pendidikan Akal

Dalam membina akal, Islam sangat memotivasi umatnya untuk menuntut ilmu. Banyak dalil-dalil dalam al-Quran yang menunjukkan akan hal itu, diantaranya:

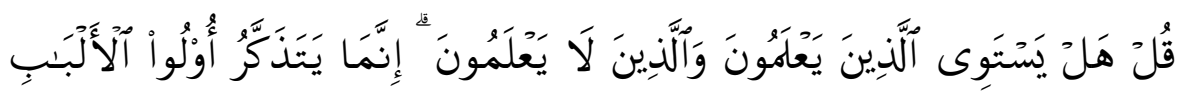

"Katakanlah: "Adakah sama orang-orang yang berilmu dengan orang-orang yang tidak berilmu? Sesungguhnya orang-orang yang berakallah yang dapat mengambil pelajaran”. (QS. Az-Zumar: 9).

Dan juga FirmanNya Taala:

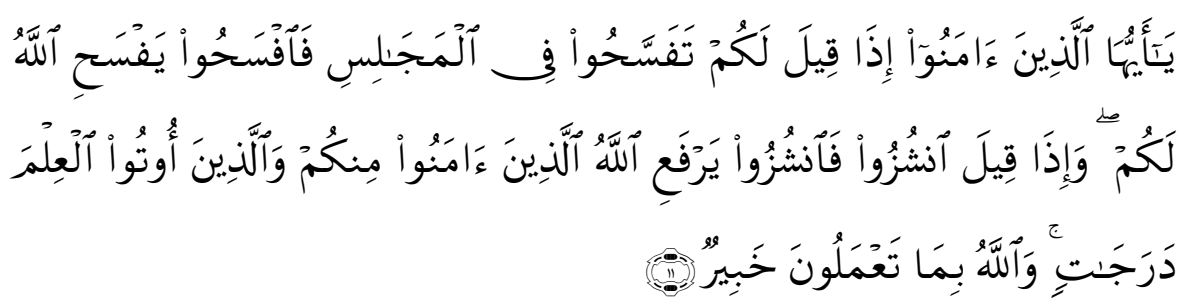

“Wahai orang-orang yang beriman! apabila diminta kepada kamu memberi lapang di dalam majlis maka lapangkanlah supaya Allah membeli kelapangkan untuk kamu. dan apabila diminta kamu bangun maka bangunlah, supaya Allah meninggikan darjat orangorang yang beriman diantara kamu, dan orang-orang yang diberi ilmu pengetahuan beberapa darjat. Dan (ingatlah), Allah Maha Mengetahui terhadap apa yang kamu lakukan. (al-Mujadilah: 11)

Disamping itu Islam juga menjaga dan memelihara akal dari hal-hal yang merusaknya, seperti khamar, kepercayaan pada tahyul dan khurafat, karena semuanya dapat merusak akal sehat manusia. Firman Allah swt:

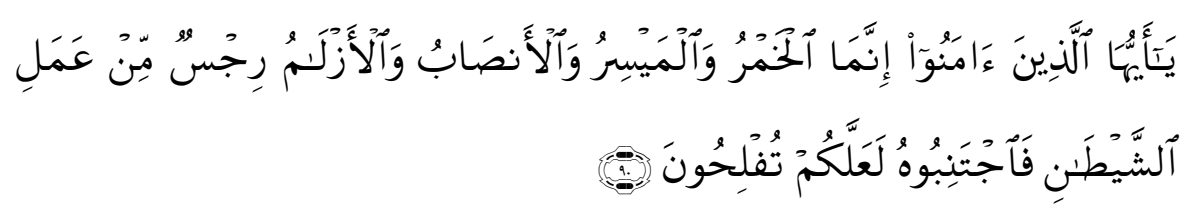


"Wahai orang-orang yang beriman! Sesungguhnya arak, judi, pemujaan berhala, dan mengundi nasib dengan anak panah, adalah kotor (keji) dari perbuatan syaitan. oleh itu hendaklah kamu menjauhinya supaya kamu beruntung. (QS. Al-Maidah: 90)

3. Pendidikan Jasmani

Pembinaan jasmani diawali dengan memakan makanan yang baik. Di dalam alQuran Allah memerintahkan umat manusia untuk makan makanan yang halal lagi baik. Firman Allah swt:

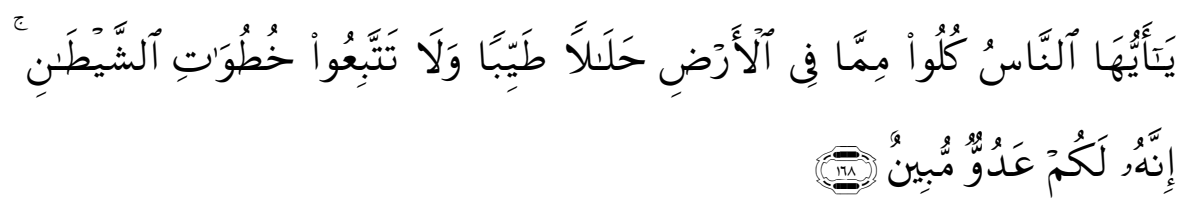

"Wahai sekalian manusia! makanlah dari apa yang ada di bumi yang halal lagi baik, dan janganlah kamu ikuti langkah-langkah Syaitan; karena sesungguhnya Syaitan itu adalah musuh yang nyata bagi kamu”. (QS. al-Baqarah: 168.)

Dengan mengkonsumsi makanan yang halal dan baik jasmani akan sehat, sebaliknya menkonsumsi makanan yang tidak baik lagi haram tubuh manusia akan rusak. Karenanya Islam melarang menkonsumsi segala jenis makanan yang dapat merusak tubuh manusia. Daging babi, bangkai, darah, rokok, minuman keras, diharamkan karena menimbulkan kemudharatan bagi tubuh manusia. Firman Allah swt:

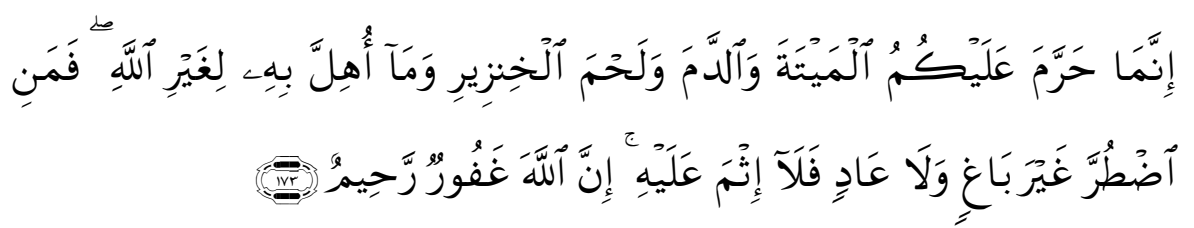

"Sesungguhnya Allah hanya mengharamkan kepada kamu memakan bangkai, darah, daging babi, dan binatang-binatang yang disembelih tidak dengan nama Allah. Maka siapa terpaksa (memakannya kerana darurat) sedang ia tidak mengingininya dan tidak pula melampaui batas maka ia tidak berdosa. Sesungguhnya Allah Maha Pengampun, lagi Maha Penyayang. (QS. Al-Baqarah; 173) 


\section{PENUTUP}

Kajian tentang konsep pendidikan dalam al-Quran merupakan kajian yang sangat menarik diikuti. Sebab menyangkut kajian tentang metode Rasulullah saw dalam mendidik sahabatnya. Metode itulah yang telah berhasil melahirkan generasi terbaik sepanjang masa. Generasi yang dipuji oleh Allah swt lewat firmanNya:

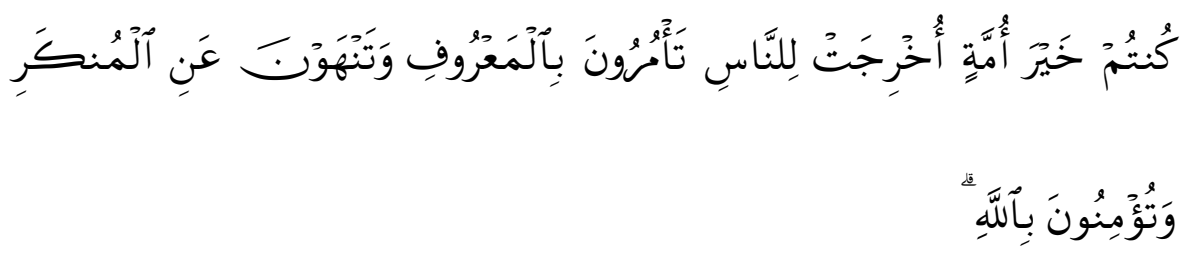

"Kalian adalah umat terbaik yang dikeluarkan untuk manusia, mengajak kepada yang ma'ruf dan mencegah dari yang munkar serta beriman kepada Allah”. (QS. Ali Imran: 110).

Merekalah manusia seutuhnya. Mulia di dunia, bahagia di akhirat. Namun titel umat terbaik yang Allah sandangkan kepada generasi awal tersebut, bukan tidak mungkin bisa diraih oleh generasi sekarang. Syaratnya tentu dengan kembali menerapkan metode dan manhaj yang telah dirintis oleh generasi pertama dulu.

\section{DAFTAR PUSTAKA}

\section{Al-Quranul Karim}

Abu Daud, t.t, Sunan Abu Daud, Beirut: Dar al-Kutub al-'Arabi.

Abuddin Nata, 1997, Filsafat Pendidikan Islam, Jakarta: Logos Wacana Ilmu.

Abu Hasan Ali al-Hasani an-Nadawi, Maza Khasiral 'Alam bi Inhithatil Muslimin.

Ahmad bin Hambal, t.t, Musnad Ahmad Bin Hambal, Kairo: Muassasah Qurtuba.

As-Suyuthi, 2003, Ad-Dur Mantsur fi Tafsir bil Ma’tsur, Kairo: Dar Hijr.

Bukhari, 1987, Shahih al-Bukhari, Kairo: Dar as-Sya'ab.

Hakim, 1990, Mustadrak 'ala as-Shahihain, Beirut: Dar al-Kutub al-Ilmiah.

Ibnu Qayyim al-Jauziyah, 1971, Tuhfatul Maudud bi ahkamil maulud, Damaskus: Dar al-Bayan.

Muhammad Qutb, 2001, Manhaj Tarbiyah Islamiyah, Kairo: Dar Syuruq.

Muhammad Syadid, t.t, Manhaj al-Quran fi at-Tarbiyah, Kairo: Dar Tauzi’ wa Nasyr.

Sulaiman bin Muhammad, al-Anwar fi sirati an-Nabiyi al-Mukhtar. 